\title{
Across the Straits from Port au Choix: Mobility, Connection, and the Dorset of Southern Labrador
}

\author{
Marianne P. Stopp ${ }^{1}$
}

(Received 22 February 2016; accepted in revised form 4 August 2016)

\begin{abstract}
Priscilla Renouf's more than 30 years of research on the human history of the Port au Choix peninsula was longue durée in execution as well as in perspective and contribution, resulting in notable insights into adaptations at Port au Choix itself and on the island of Newfoundland. This paper finds inspiration in Renouf's work at the site of Phillip's Garden (EeBi-1) on the Port au Choix peninsula. It proposes a model of integration and shared social context between Dorset in southern Labrador and Dorset in northwestern Newfoundland. Mobility and interconnection, key hallmarks of northern forager societies, are suggested through multiple lines of evidence that include the proximity and contemporaneity of sites in the two regions, the evidence of long-distance networks for exchange of Ramah chert, and the requirements of travel imposed by the twice yearly harp seal migration, which passed close to the Port au Choix peninsula in spring but followed the Labrador shore in late autumn.
\end{abstract}

Key words: Dorset culture; northern foragers; southern Labrador; Strait of Belle Isle; mobility; northern forager interaction; harp seal migration

RÉSUMÉ. La recherche sur l'histoire humaine de la péninsule de Port au Choix effectuée par Priscilla Renouf a duré plus de 30 ans. Elle a été de longue durée dans son exécution, mais également dans sa perspective et sa contribution, renseignant de façon significative sur les adaptations de Port au Choix même et de l'île de Terre-Neuve. Cette étude est inspirée des travaux de Priscilla Renouf réalisés au site de Phillip's Garden (EeBi-1) dans la péninsule de Port au Choix. Il propose un modèle d'intégration et un contexte social partagé entre le Dorset du sud du Labrador et le Dorset du nord de Terre-Neuve. La mobilité et l'interconnexion, caractéristiques essentielles des sociétés fourragères du Nord, sont suggérées sous forme de sources de données multiples, dont la proximité et la contemporanéité des sites des deux régions, la preuve de l'existence de réseaux pour l'échange de chert de Ramah sur de longues distances et les exigences en matière de déplacement imposées par la migration semestrielle du phoque du Groenland, laquelle passait près de la péninsule de Port au Choix au printemps, et suivait la côte du Labrador vers la fin de l'automne.

Mots clés : la culture de Dorset; chasseurs-cueilleurs du Nord; sud du Labrador; détroit de Belle Isle; mobilité; interaction avec les chasseurs-cueilleurs du Nord, migration du phoque de Groenland

Traduit pour la revue Arctic par Nicole Giguère.

\section{INTRODUCTION}

The impressive continuity of Dorset culture in the Canadian Northeast is widely recognized by archaeologists. Renouf (1991, 1993, 1994, 1999) noted that central mechanisms of Dorset long-term continuity were risk reduction, for which predictable species were especially important, and the interplay of mobility and human ties that allowed the Dorset to exist successfully in western Newfoundland for about 800 years. Renouf recognized that Dorset on Newfoundland's northwestern coast had connections with Dorset island-wide and on the Quebec North Shore. She also acknowledged the likelihood of "more indirect connections" farther afield that "would have maintained sharing and information networks with groups farther north" (Renouf, 1994:191).
Dorset sites in that "farther north" are not that far away. This paper considers archaeological, analogical, and inferential evidence to propose that Dorset in southern Labrador were part of a regional network that included Dorset in northwestern Newfoundland, with specific reference to the site of Phillip's Garden on the Port au Choix peninsula (Fig. 1). Mobility and interdependence are here considered fundamental tenets of Dorset social action and, ultimately, of long-term cultural continuity on opposite shores of the Strait of Belle Isle. Forager groups who come together ensure cultural continuity by maintaining contacts over a lifetime and across generations, thus perpetuating not only a gene pool, but also a meme pool of social memory and narratives, skills, and landscape knowledge that are all integral features of northern hunter-gatherer societies (Binford, 1980; Spielmann, 1986; Kelly, 1992; Cruikshank, 2015).

\footnotetext{
${ }^{1}$ Archaeology and History Branch, Parks Canada, Government of Canada, 30 Victoria Street, (PC-03-L), Gatineau, Québec J8X 0B3, Canada; marianne.stopp@pc.gc.ca

(C) The Arctic Institute of North America
} 


\section{THE DORSET SITES - AN OVERVIEW}

The settlement of Arctic-adapted cultures in Newfoundland and Labrador began ca. 4000 BP with the arrival of Pre-Dorset in northern Labrador, followed by the Groswater phase ca. 2800 BP, through to the most extensive period of Dorset settlement (often considered in terms of Early, Middle, and Late Dorset) from ca. 2500 BP to 800 BP. Three millennia of occupation and more than 900 sites (Provincial Archaeology Office, 2015) testify to a lengthy and substantive cultural continuum.

\section{NW Newfoundland - Phillip's Garden (EeBi-1), Port au Choix Peninsula}

Phillip's Garden is one of the largest known Dorset sites in the Canadian Northeast. It is characterized by remarkable morphological preservation, in particular of semisubterranean winter houses, as well as fauna-rich middens, unique artifacts, and lengthy site use (from 1990 to $1180 \mathrm{cal}$ BP). Many rich veins of cultural data have led to research that has contributed substantively to the conceptualization of "Dorset" in Newfoundland and Labrador. The site's position on the headland was a strategic location from which harp seals were hunted in the spring during their northward migration out of the Gulf of St. Lawrence towards Arctic waters. The herd passes offshore in the thousands, moving with the sea ice, in late March and early April. At that time, a recurring ice lead opens up just off the Port au Choix peninsula, making this site the only point along the island's western coast where migrating seals are relatively close to shore (Leblanc, 1996; Bell and Renouf, 2008:80; Renouf, 2011b:135). The adjective "permanent" has been used to describe Phillip's Garden in the sense of a persistent place on the landscape used regularly for millennia (Renouf, 1991, 2011a:2). Renouf stressed that the spring harp seal migration was the chief reason for settlement at this place because of the particular conditions that brought the herd mass closer to shore. Middens at the site are dense with harp seal bones from the spring hunt, although a small sample of faunal remains of 10-month-old juveniles points to carcasses from the early winter seal hunt (Renouf, 2003; Hodgetts, 2005; Bell and Renouf, 2008).

\section{Southern Labrador Dorset sites}

Over the past 20 years, over 40 Dorset sites have been recorded along the southern Labrador coast between the Blanc Sablon area of the Quebec Lower North Shore and Sandwich Bay to the north (Fig. 2, Table 1; Fitzhugh, 1982; Auger and Stopp, 1989; Plumet et al., 1994; Stopp, 1997; Pintal, 1998). Because these sites have hardly been considered in analyses of the Dorset world, somewhat more descriptive detail is given by way of introduction.

The locations of these sites illustrate the ecozones that Dorset exploited in southern Labrador, which range from terrestrial to freshwater to marine. The site positions range

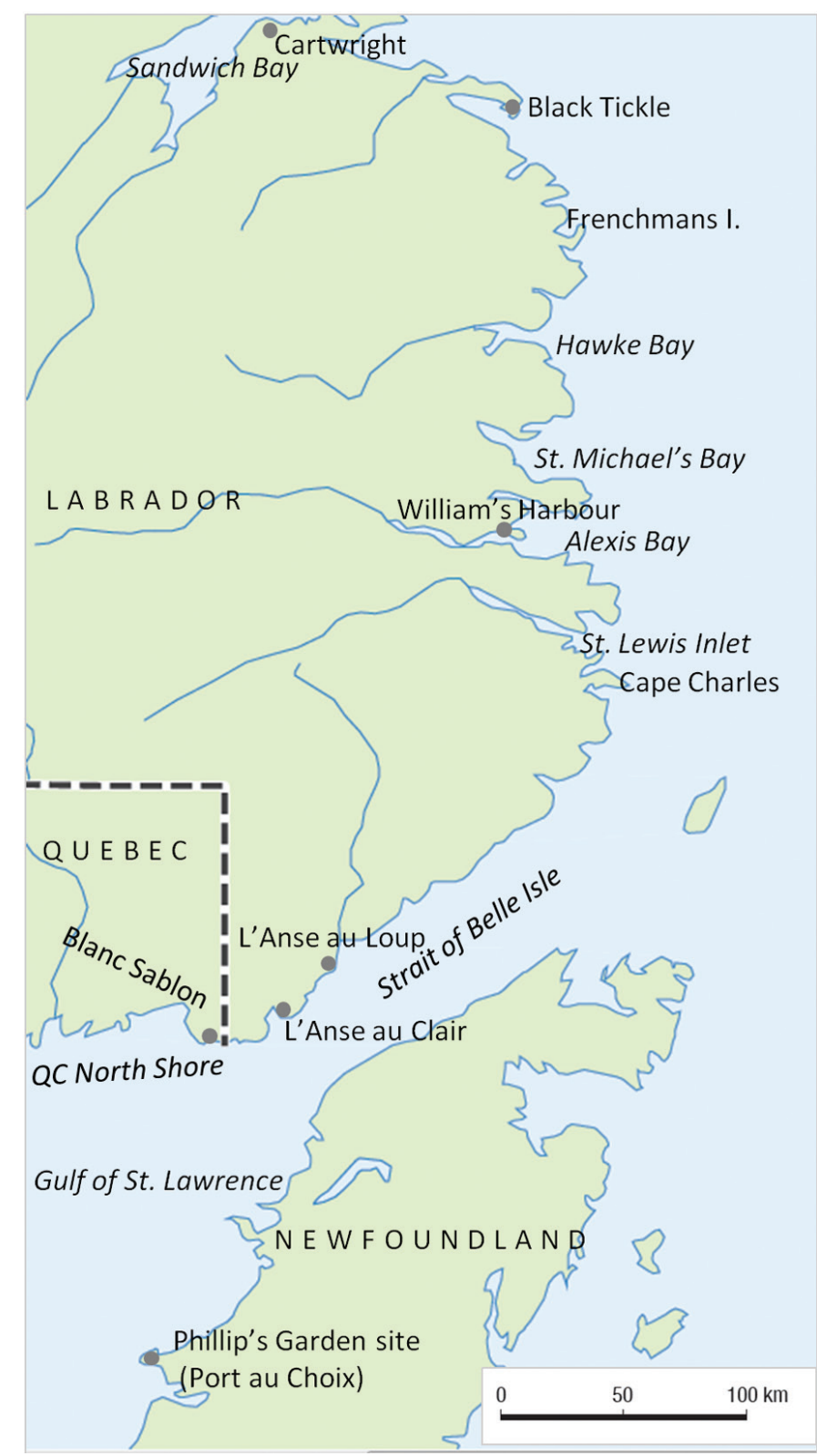

FIG. 1. Map of the study area showing place names mentioned in text.

from well within fjord-like bays to the outermost islands. Cultural material, where undisturbed, occurs near the base of the $12-15 \mathrm{~cm}$ thick peat overburden and generally rests atop former beach layers of coarse sand or gravel. Lithics include Newfoundland cherts, Ramah chert, unidentified local cherts, and quartz crystal, in the form of flaking debris, microblades, scrapers, and Dorset convex-based endblades (Figs. 3, 4, 5).

The importance of these sites as markers of northern forager adaptations (and of Dorset adaptations far to the south of their original Arctic points of origin) cannot be underestimated. Because southern Labrador is characterized by coastal emergence (Quinlan and Beaumont, 1981; Bell et al., 2005), site size and regional distribution are minimally compromised. For the study of ancient hunter-gatherer cultures, these sites represent 


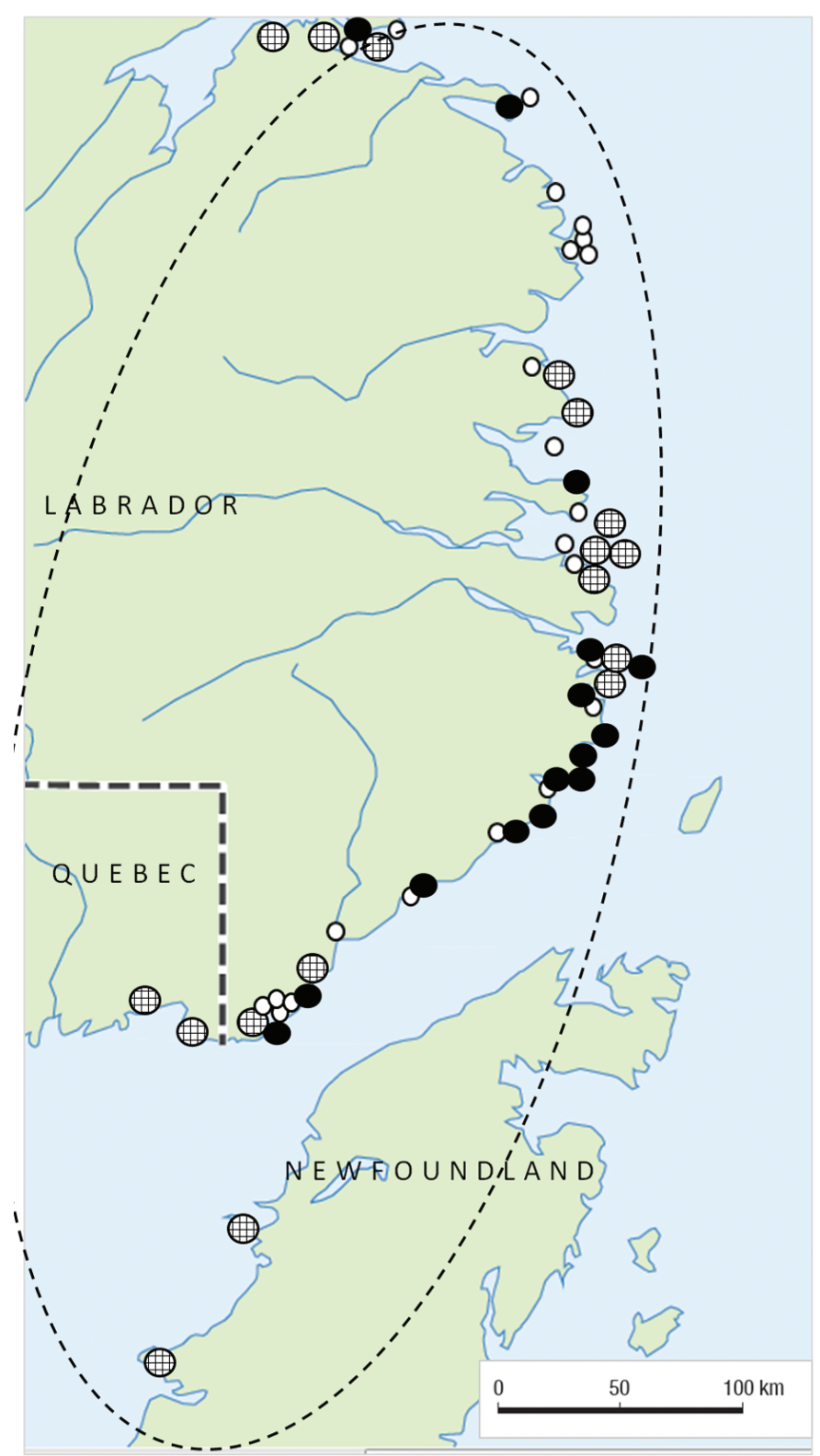

$\oplus$ Large Dorset sites $->200 \mathrm{~m}^{2}$

- Small Dorset camps- $<200 \mathrm{~m}^{2}$

\section{- Pits/Storage $-10 \mathrm{~m}$ asl or less}

FIG. 2. Location of large and small Dorset sites in southern Labrador. The dotted line marks the study area and Dorset network zone considered in this paper. Other networks would have extended in other directions, such as between northwestern Newfoundland and White Bay or Notre Dame Bay, or towards southern Newfoundland.

a unique set of relatively undisturbed data across a broad coastal expanse.

Dorset sites in southern Labrador can be arbitrarily divided into two groups on the basis of their areal spread. Larger sites (Fig. 2) with an area $200 \mathrm{~m}^{2}$ or greater are found both as surface distributions and below the surface. Subsurface cultural layers range from 5 to $8 \mathrm{~cm}$ in thickness
TABLE 1. Dorset sites in the study area (ordered by Borden number).

\begin{tabular}{|c|c|c|c|}
\hline Borden \# & Site name & $\begin{array}{c}\text { Elevation } \\
\text { approx. m asl) }\end{array}$ & $\begin{array}{c}\text { Approximate } \\
\operatorname{area}^{1}\left(\mathrm{~m}^{2}\right)\end{array}$ \\
\hline EiBg-11 & Le site du Delta & 5 & $>3000$ \\
\hline EiBg-43 & Blanc Sablon & 9 & 1000 \\
\hline EjBe-35 & L'Anse au Diable 4 & 5 & - \\
\hline ElBa-2 & Rocketts Cove 1 & 3 & - \\
\hline EkBc-1 & Red Bay - Area M & 5 & - \\
\hline $\mathrm{FbAv-7}$ & Cape Charles 2 & 17 & 620 \\
\hline FbAv-9 & Wall Island 2 & 12 & 1 \\
\hline FbAv-11 & Caribou Run 1 & 1.4 & 4 \\
\hline $\mathrm{FbAv}-12$ & Sand Cove 1 & 3 & 400 \\
\hline FbAv-17 & Edward Pye & 4 & - \\
\hline FbAw-6 & Assizes Island 1 & 4 & 400 \\
\hline FbAw-7 & Assizes Island 2 & 5 & 200 \\
\hline $\mathrm{FcAv}-4$ & Pardy Site & 15 & $>3000$ \\
\hline $\mathrm{FcAv}-5$ & Sealing Bight 1 & 12 & 6 \\
\hline FdAw-2 & Granby Island 1 & 2.5 & 3000 \\
\hline $\mathrm{FdAw}-3$ & Granby Island 2 & 8 & 12 \\
\hline FdAw-4 & Sandy Hook 1 & 5 & 225 \\
\hline FdAw-5 & St. Francis Harbour Bight 1 & 5 & 25 \\
\hline FdAw-8 & Fishing Ships Harbour 1 & 7 & 200 \\
\hline FeAw-3 & Butler Island 1 & 3 & 10 \\
\hline FeAx-3 & North Island 1 & 5 & 2000 \\
\hline FfAw-1 & Cooper Island 1 & 3 & 4000 \\
\hline FfAw-2 & Cooper Island 2 & 4 & 40 \\
\hline FfAx-1 & Snug Harbour 1 & 6.5 & 25 \\
\hline FhAw-5 & Fling Islands 1 & 21 & 50 \\
\hline FhAw-6 & Frenchmans Run 1 & 3.4 & 4 \\
\hline FhAw-7 & Frenchmans Island 1 & 4.9 & 50 \\
\hline FhAw-8 & Seine Island 1 & 4 & 4 \\
\hline FhAw-11 & Bed Head 1 & 4 & 20 \\
\hline FiAw-3 & Black Tickle 2 & 5 & 2000 \\
\hline FjAx-5 & Lynch Island 1 & 3.5 & 6 \\
\hline FkBc-1 & Table Bay 1 & 3 & 2 \\
\hline FkBc-2 & Black Island/Grady Harbour 2 & 5 & 25 \\
\hline FkBc-4 & Black Island/Grady Harbour 3 & 4.4 & 400 \\
\hline FkBc-6 & Little Black Island 2 & 4.2 & 12 \\
\hline FkBc-7 & Grady Island 1 & 5 & 25 \\
\hline FkBc-8 & Grady Island 2 & 12 & 500 \\
\hline FkBc-11 & Black Island/Grady Harbour 4 & 3 & 25 \\
\hline FkBd-16 & Table Bay 2 & 5 & 16 \\
\hline FkBe-19 & Flossie Curl 1 & 3.1 & 300 \\
\hline FkBg-2 & Huntingdon Island 3 & 8.1 & 4 \\
\hline FkBg-4 & Huntingdon Island 6 & 4.6 & 25 \\
\hline FkBg-5 & Coastguard Radio Station & 11 & 1000 \\
\hline FlBg-3 & Horse Chops Island 3 & 4.9 & 100 \\
\hline
\end{tabular}

${ }^{1}$ Site size is based on surface distribution, test-pitting, or both, not on excavation.

and also tend to have bone preservation and a range of lithic remains. Large sites are generally situated in protected coves or not facing the open sea and are found near the mouths of the deep inlets, including St. Lewis Inlet, Alexis Bay, St. Michael's Bay, Hawke Bay, and Sandwich Bay. They are strategically positioned to exploit the early winter harp seal migration, described below. Larger site size suggests more people in one place who would have acted as the coordinated labour force needed to capture and process a large number of moving seals in a relatively short time. These sites were also the same locations chosen in the 16th to 18th centuries by Inuit, and again in the 18th to 20th centuries by European settlers, whose ways of life were equally dependent on the seasonal appearance of harp seals. As a result, not all large sites are undisturbed: some (i.e., $\mathrm{FbAv}-12, \mathrm{FcAv}-4$ ) have 


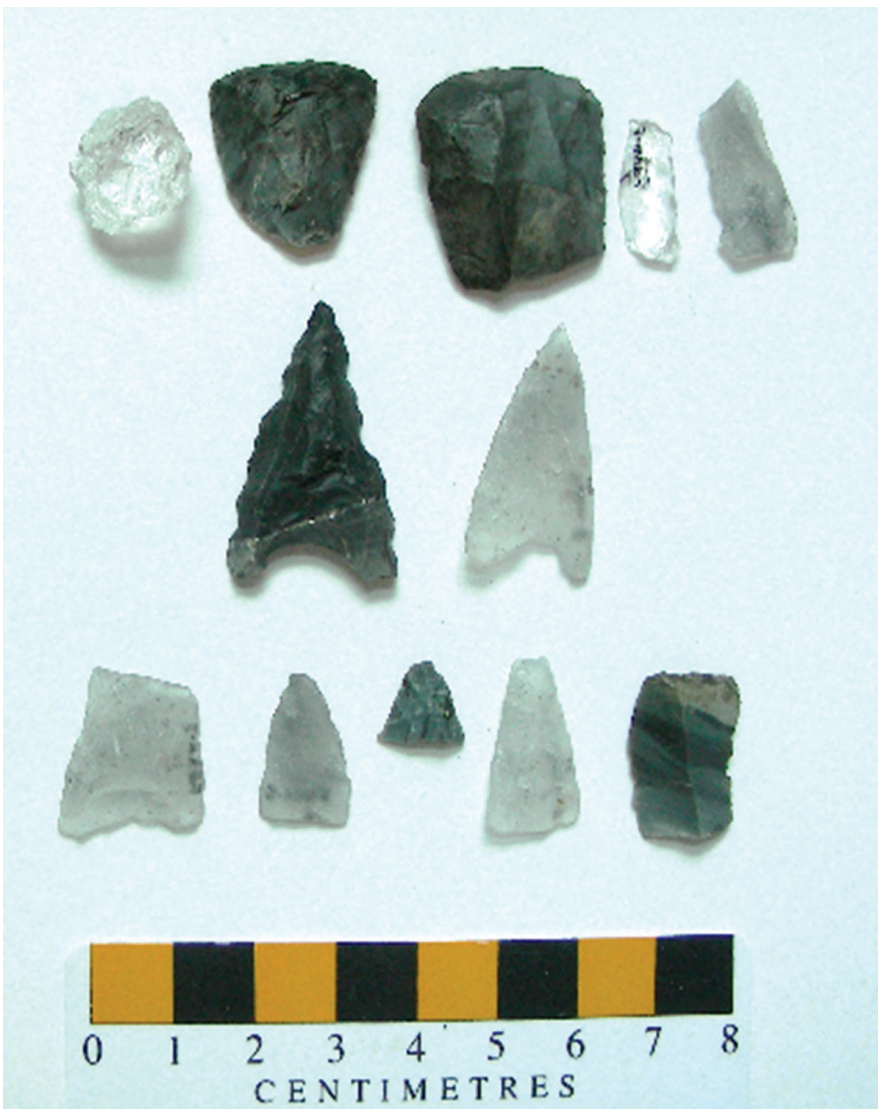

FIG. 3. Dorset lithics from St. Francis Harbour Bight 1 (FdAw-5), in Alexis Bay.

been exposed by wind erosion, and others disturbed by the impacts of re-use over time, especially modern community developments at L'Anse au Clair, L'Anse au Loup, William's Harbour, Black Tickle, and Cartwright.

Smaller sites are those under $200 \mathrm{~m}^{2}$ in area (Fig. 2). They tend to have less well defined cultural layers, with scarce lithic material consisting mainly of chipping debris and some retouched flakes. The majority of small Dorset camps were found through test-pitting. Their positions range from within bays in the southern part of the study area (FbAv-9, FbAw-6, FbAw-7, FcAv-5, FfAx-1, FhAw-5, FkBd-16, FkBe-19, FkBg-2, FkBg-4) to outer islands between Sandwich Bay and Frenchmans Island (FcAw-3, FhAw-8, FhAw-11, FjAx-5, FkBc-1, FkBc-6, FkBc-7, FkBc-11). Because they lack diagnostic artifacts and the radiocarbon samples are too small for dating, these camps are identified as Dorset on the basis of lithic types and their depth below surface. Despite their ephemerality, they add considerably to our understanding of Dorset settlement patterns and land use, which have generally been viewed through the lens of large or culturally rich sites. Their interpretive strength lies in their representation of discrete events, rather than more challenging palimpsests, and what they reveal about Dorset resource diversity beyond the seal hunt. Their various positions on the landscape suggest salmon runs, berrying, birding, hunting inner-water seal species such as harbour

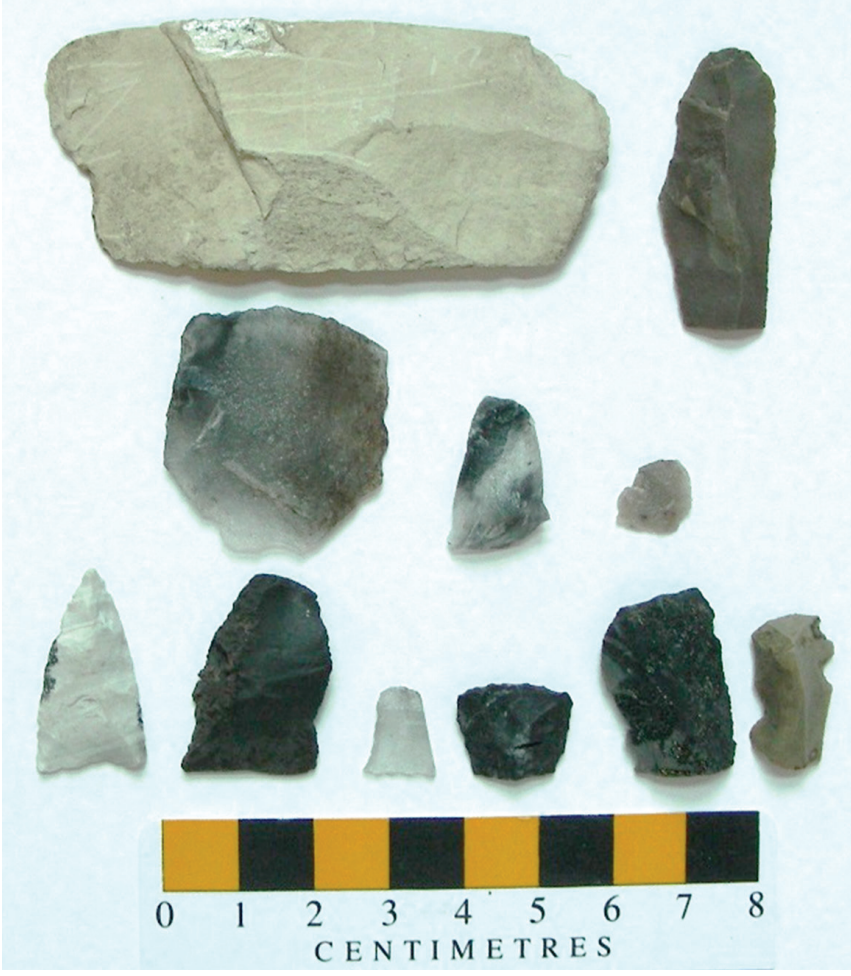

FIG. 4. Dorset lithics from the Pardy Site (FcAv-4), between St. Lewis Inlet and Alexis Bay.

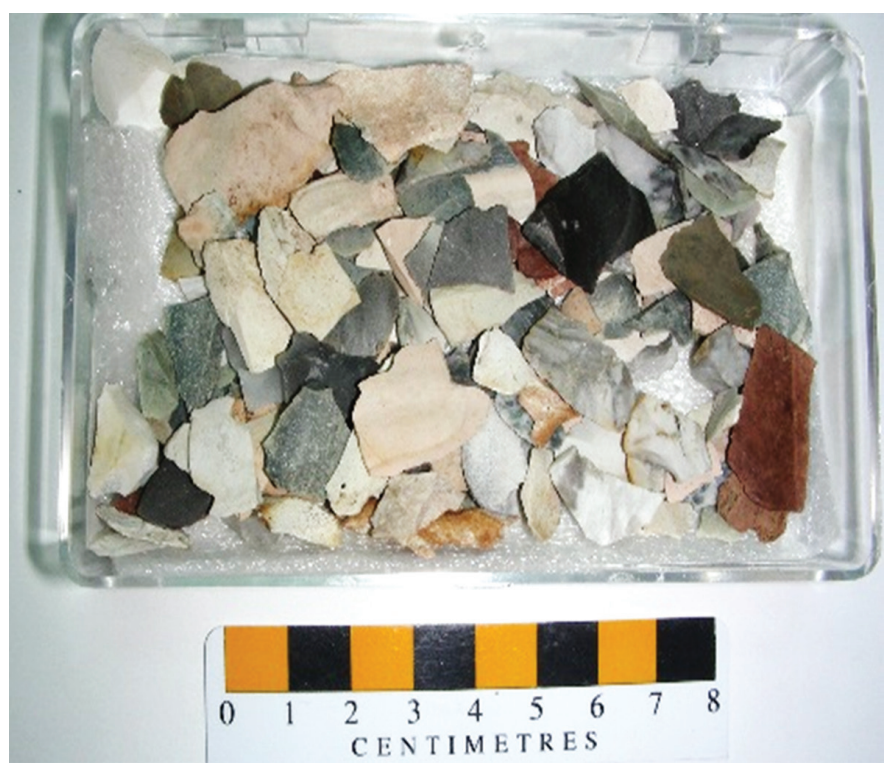

FIG. 5. An assortment of lithic types from Sand Cove 1 (FbAv-12), at the mouth of St. Lewis Inlet. Gray and patinated flakes mix with black Kaumajet and Ramah cherts.

seals, and caribou hunting. Their temporary nature also draws a connection to the larger, more established camps.

In addition to settlement sites, pits in relict cobble beaches characterize the cultural landscape of southern Labrador. Elsewhere, these pits have been interpreted as storage features (Stopp, 1994, 2002), although they lack diagnostic material. They are $1-3 \mathrm{~m}$ in diameter and cluster 
at elevation ranges of $1-5 \mathrm{~m}$ above sea level (asl) and at $10 \mathrm{~m}$ asl. Elevation is not a reliable way of either determining cultural affiliation or dating these features. Pits in the lower elevation range may have been constructed by Dorset, by later Inuit foragers, or both. Although higher elevation sites in Labrador are often suggested as older, they could also have been created by later peoples. Thus, the possibility of Dorset using relict cobble beach pit storage strategies is propositional, but it can help us to understand how large quantities of meat were managed. Pit features in southern Labrador are found in areas where the early winter seal migration passes very close to shore and would have served as a means of storing a large amount of nutritional fat and protein for future use (see below).

\section{IDENTIFYING DORSET NETWORKS: SOUTHERN LABRADOR AND NORTHWESTERN NEWFOUNDLAND}

\section{Mobility and Connection}

The proposal that southern Labrador Dorset and northwestern Newfoundland Dorset ranged across the Strait of Belle Isle and had connections with each other is based on three core assumptions: a) that Dorset were capable of mobility, b) that they exercised mobility, and c) that there was movement between the two regions. The semi-subterranean houses and deep middens at Phillip's Garden may suggest that the Dorset people there were relatively sedentary; however, these same traits are also characteristic of other mobile foragers of the Northeast such as the early Innu of central Labrador or the Beothuk of Newfoundland. As noted, mobility is here considered to be an intrinsic component of cold-climate forager cultures in the study area. Interpretations that limit mobility would remove an effective basis for cultural transmission, for cultural maintenance, and for creating the concentration and dispersion of related and unrelated camps and families that characterize forager "interconnection networks" across space (Binford, 2001:471; also Kelly, 1992; Lee and Daly, 1999; Cannon, 2014; Cummings et al., 2014).

The range of site locations across several ecozones in southern Labrador also suggests that Dorset foragers were mobile, whether on foot or using technical support in the form of vessels, sleds, and snowshoes. It is difficult to conceive of a Dorset way of life without some form of waterborne transportation, which would have had a significant and positive impact on net productivity and social developments. Vessels would have been the means of residential and logistical moves throughout the region: they facilitated multiple trips and greater trade because they transported bulk and weight (Ames, 2002). No evidence of vessels, dogs, or snowshoes has yet been found at Dorset sites in the study area, but Phillip's Garden has notably yielded 624 sled-shoe fragments with dates that span the site's ca. 800-year occupation. Their use is tied to the transportation of seal carcasses from shore-edge to the site, but also to movement to more distant camps (Wells and Renouf, 2014). Made of whalebone, these sled-shoes are clear indicators of cold season presence at the site, but also, and relevantly, of cold season mobility.

Mobility supported the accumulation of knowledge sets about land- and seascapes that included the open sea, coastlines, riverine ecotones, forested areas, and barrenland. Such knowledge had to be sustained over the long term in order to visit and revisit food harvesting locales, toolstone quarries, and settlement locations and to choose effective travel routes for cold and warm seasons. The practice of returning to a region, or the "principle of return in space" (Carlstein, 1982:70), is an essential component of mobility and ultimately of forager cultural success over the long term. Thus, significant prime movers of culture change would have included the negation of mobility, isolation, and the inability to move to another resource place, as well as the influx of other populations that cut off access to resource areas.

The social, non-material aspects of mobility that connect foragers and support culture are increasingly being considered. The idea of "the trail as home" (Aporta, 2009) recognizes that movement or mobility is at the essence of the forager way of life, for which trails or distances covered are as significant as camps. Mobility and the meaning of movement through the landscape are ways of getting at how culture and identity were sustained (Cannon, 2014:3). Distances may be short or may require days and months of travel, but along the way, familiarity with landscape and with related factors such as meteorological knowledge combine to create preferred trajectories of continuous home, punctuated by camps. In the context of this paper, Dorset watercraft travel would have enabled movement across and along aquatic "trails" and, following Aporta (2009), both water and land travel would have been part of the continuous home. This view of mobility packs campsites and movement, landscape knowledge, connections to people, sacred geographies, resources, householding, and engendered action into experiences that, to a certain extent, are identifiable through archaeology (Weig, 2013; David et al., 2014:1179). Mobility so conceived becomes a relational phenomenon that involves both relations between people and those between the history of forager peoples and the identities gained from their lived landscape(s).

Post-processual approaches to the archaeology of mobility understand it in terms broader than food cycles, survival imperatives, or choices determined by optimization and least-energy-expended. Research that gives priority to calculated decisions of economic value and to the narrowly defined forager territories of ecological models inevitably "strips nomadic people of inherently active choices" by delimiting how and why to move from place to place, and it strips archaeologists of access to potentially rich veins of analysis (Scheiber and Finley, 2011:169). The study of mobility may present a conceptual impasse for modern-day, non-forager researchers (Cummings, 2013; Cummings et 
al., 2014). We likely underestimate or cannot conceptualize travel distances, or the willingness or inclination of past peoples to undertake journeys by watercraft, by sled, and on foot. Ethnohistoric evidence from Labrador offers the examples of the Inuit, who routinely voyaged from the bays north of Sandwich Bay to Cape Charles or northwestern Newfoundland and sledded in winter from Ungava Bay to the Labrador coast. The Innu of Labrador recognized countless trail systems and waterways for travelling from central Labrador eastward to the coast, southward to the Gulf of St. Lawrence shore, and to many points in between during all seasons.

The sites described above for southern Labrador-small, short-term bivouac-type camps, and larger, longer-term camps - testify to the lattice-work of connections with landscape (and resources, and people) created by logistical and residential mobility. With the Strait of Belle Isle as a traverse or a water route, rather than a barrier, these networks would have extended to Newfoundland.

\section{Contemporaneity}

Chronological overlap adds to the likelihood of persistent contacts between the two regions. Radiocarbon dates collected from nine Dorset sites in southern Labrador show a ca. 800 year overlap with a bank of 48 Dorset dates from Phillip's Garden (Fig. 6). Paleo-climate studies on Newfoundland's Northern Peninsula have suggested that Dorset presence came to an end around ca. $1180 \mathrm{cal}$ BP, during a period of warming that would have undermined sea ice conditions and may have altered seal availability (Bell and Renouf, 2011). Three dates from the southern Labrador coast (Beta-48308, -56251, -56253) show that Dorset were still settled in St. Michael's Bay and farther north in Sandwich Bay after the end-date for Port au Choix. Resettlement toward the north may have been a riskreduction decision that brought a dwindling population together for a short time (Stopp, 2008:118).

\section{Toolstone Acquisition as an Indicator of Connection}

The exchange and movement of Ramah chert from its northern outcrops in Ramah Bay near the tip of Labrador $\left(57^{\circ} 58^{\prime} 46^{\prime \prime} \mathrm{N}, 62^{\circ} 20^{\prime} 51^{\prime \prime} \mathrm{W}\right)$ to southern points provides the best evidence known at present for complex and extensive networks of exchange - and interconnection - that existed for millennia in northeastern North America (Loring, 2002; Stopp, 2008). Movement of Ramah chert began 5000 years ago in northern Labrador during the Archaic period (ca. 5000-3500 BP), continued from the Pre-Dorset through to the Dorset period (ca. 4000-1000 BP), and appeared again during the Late Precontact Amerindian period (ca. $1800-450 \mathrm{BP})$. At different times and in varying quantities over time, Ramah chert was exchanged throughout the Maritimes, westward to James Bay, into the Huronia region of Ontario, and southward into New England.
From their earliest arrival in Labrador 4000 years ago, Arctic-adapted cultures settled in the Ramah Bay area in northernmost Labrador and began to use Ramah chert as one of a range of toolstone types. Throughout both the PreDorset and Dorset periods in Labrador and Newfoundland, Ramah chert was a persistent presence in lithic assemblages alongside quartz and other cherts. Its usage rose in Labrador during the late Groswater period (ca. 2200 BP; Loring and Cox, 1986) and again in northern Labrador during the late Dorset period (ca. 1350-1100 cal BP). For the latter period, Ramah chert accounts for close to $100 \%$ of the flaked stone tools found on sites (Stopp, 2013, and references). Field samples indicate that southern Labrador Dorset sites had low but steady quantities of Ramah chert alongside other cherts and quartzes. In northwestern Newfoundland, sampling of lithic assemblages from six dwellings at Phillip's Garden also suggests that Ramah chert usage was persistent but low relative to the use of local chert types (in particular Cow Head chert) over time, rising somewhat during the late Dorset period (Anstey and Renouf, 2011; Renouf, 2011b). Significantly, cherts from Ordovician deposits that run the length of western Newfoundland appear in persistent quantities on Groswater and Dorset sites throughout coastal Labrador and also provide archaeological evidence that coastally adapted peoples devised strategies to maintain long-distance connections (Loring and Cox, 1986; Nagle, 1986).

Exchange includes the point of quarrying, the journey to exchange points, and the trade transaction, as well as resulting communication and interaction. As a subset of mobility, exchange is recognized as "a key process in the creation and circulation of culture itself" (Agbe-Davies and Bauer, 2010:19). Exchange systems crosscut kinship, language, and territorial boundaries. For the Dorset in the study area, the presence of Ramah chert on sites, whether in large or small proportions, demonstrates connections and long-distance mobility and negates notions of isolation. The movement of Ramah chert appears to have been central to dynamic regional networks and to maintaining Dorset society and identity across space. Overall, the persistent transport of Ramah chert over time suggests that its acquisition and circulation among the Dorset were tied to more than subsistence or utilitarian activities. Rather, "it represents the material correlates of non-utilitarian mobility" (Newlander, 2012:72) - the human interconnections that served to maintain Dorset social and informational networks (Whallon, 2006; Newlander, 2012). The journey between the quarries and the Strait of Belle Isle may have been part of an ancestral trek that passed places of connection and memory, brought contact with distant kin, and maintained ideological links with landscape. The presence of Newfoundland cherts on Dorset sites in Labrador in effect tells the same story - one of movement and connection. The intermixture of lithics from the two regions suggests opportunistic local procurement systems that would have been carried out by individuals, as well as more structured systems for moving non-local varieties over great distance. 


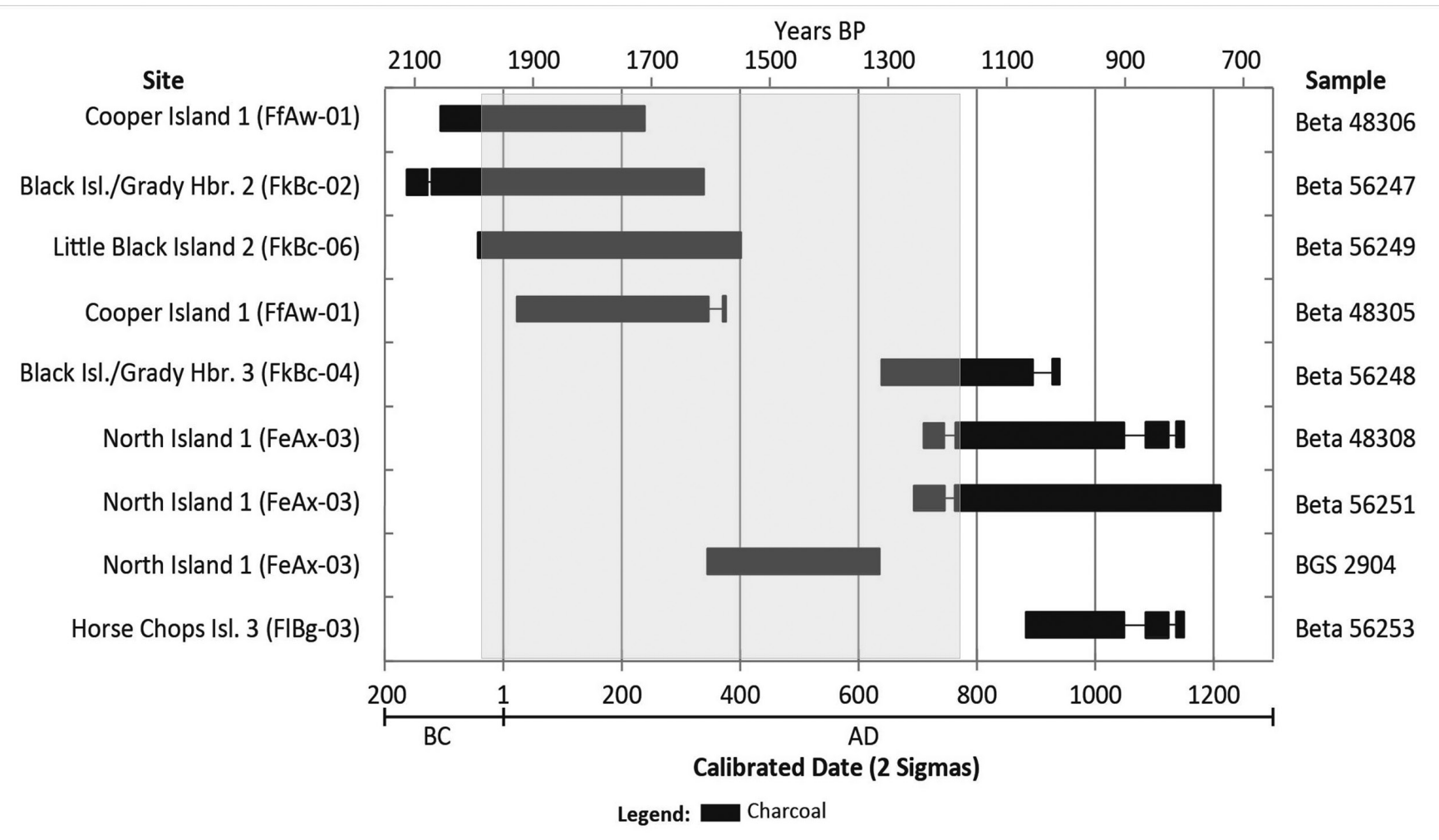

FIG. 6. The radiocarbon dates from Dorset sites in southern Labrador are shown as horizontal bars. The shaded block represents the range of radiocarbon dates from 1990 to 1180 (cal BP median age) for Phillip's Garden. The overlap of the two sets of dates represents settlement contemporaneity for both regions (dates from Stopp, 1997; Renouf, 2011b:134, 303).

\section{Mobile Resources}

Dorset sites in southern Labrador are positioned to take advantage of the annual harp seal migration, albeit not in spring, as in northwestern Newfoundland, but during the late autumn migration. Where middens have been found, for example, at Cooper Island 1 (FfAw-1) in the area of Hawkes Bay (Table 1), they are rich in seal bones like those at Phillip's Garden. Dorset people are considered specialized hunters of seals, an abundant and highly predictable resource that is high in protein and lipids. The species' predictability removed a classic choice or challenge often considered for forager peoples, namely where in the landscape to encounter high-ranked and abundant prey (Schmidt, 1998).

The different migration trajectories taken by the herd mass in late autumn and in spring offer another way of considering Dorset interconnections. The late autumn migration is notable because for much of its journey the greatest proportion of the herd stays very close to the Labrador coast, entering bays and inlets and moving between islands. At this time, seals can be caught almost anywhere close to shore. Historical records state that the autumn harp herd moved along the southern Labrador coast for a month beginning in mid-November and passed the Quebec Lower North Shore by mid-January (Sergeant, 1991). The earliest recorded observations of the southward harp seal migration are found in the journal of George
Cartwright (1792), who kept yearly notes on the arrival and movement of the harp seal herd. Cartwright also recorded that, "upon their migration Southward, they trim the shore all the way, and enter every Bay \& Harbour. The first appearance of them at Cape Charles and the adjacent places is generally about the 16th of November, and the whole are passed by on or before Christmas day" (Stopp, 2016:105).

The close-to-shore nature of the autumn seal migration contextualizes the position of large and small Dorset sites along the southern Labrador coast. Sites are positioned at ideal capture zones, including areas within the island archipelagoes, at all of the southern coast's great capes, and along narrow "tickles," which are natural funnels created by two opposing shorelines. The herd's route close to shore was conducive to capture on a large scale, making these seals especially important as a plentiful food resource just at the onset of winter. The herd's proximity to the Labrador coast in late autumn, and not to the coast of northwestern Newfoundland, raises the possibility of autumnal forays by Dorset to the "other" shore to hunt seals in preparation for winter.

Tied to the harvesting of an abundant resource are its storage at the onset of winter and the process of rendering it nutritionally useful for future use. With reference to the pit features described above, archaeological evidence of food storage systems in southern Labrador offers another reference for mobility and for networks of contact (Fig. 2). It is not out of the question that the autumn seal migration 
along the southern Labrador coast, in conjunction with a storage regime, may represent part of the subsistence cycle of western Newfoundland Dorset. Elsewhere (Stopp, 1994, 2002) I have examined how storage is integral to huntergatherer mobility. Food is stored in a number of ways that include positioning caches across the landscape, processing food (especially fat and meat) into portable units that are by their nature in a form of storage, and preserving foods by fermentation. Approaches such as these extend the nutritional usefulness of foods such as seal meat, guts, fat, and blood well beyond capture time, even into the following warm season. Forager food storage is not an adaptive measure that anchors sojourn at a camp, and it is not necessarily tied to sedentism, but can support mobility. Nor does cold season storage have to be next to a camp: it can be closer to where a resource was caught or where it could be successfully stored for long periods, such as in raised cobble beaches. A mobile way of life, moreover, would have pulled such caches into part of the "trail as home," whereby hunting and food caching in southern Labrador by Dorset from northwestern Newfoundland may be considered within the realm of possibility.

\section{CONCLUSION}

Renouf (1999) made the point that during periods of resource scarcity, hunter-gatherers on the island of Newfoundland buffered risk through links to Dorset elsewhere. This paper has suggested archaeological approaches for identifying Dorset social networks across a study area that included southern Labrador and northwestern Newfoundland. Proximity, chronological overlap, evidence of exchange, hunting of harp seals on both shores of the Strait of Belle Isle, and food storage are all known or likely components of "interconnection networks" (Binford, 2001:471) that contributed to continuity of Dorset and to their long-term success as cold-climate foragers.

These frames of reference are both proxy and direct archaeological evidence of the embeddedness of mobility, in which core (central site, or Phillip's Garden as an "important" place) and margin (a small Labrador camp) are part of a broader settlement system that represents connections. They are examples of how archaeological evidence can communicate what is frequently missing in ethnohistorical, historical, or anthropological sources, namely former long-term connectivities, or the enchainment of time, places, and people (David et. al., 2014; also Cannon, 2014). Elmer Harp (1976:119), working in the Strait of Belle Isle area, made the point that sites represent communities and people, rather than merely culture change or adaptations determined by climate and environment. The movement across space, through a known landscape and to known resource locales and kin, is thought to typify Dorset connection in the study area. Following this model, mobility turns a region into a community that is as valuable to the notion of home as the single site.

\section{ACKNOWLEDGEMENTS}

Thanks to Lisa Hodgetts and Patty Wells for their work towards honouring Priscilla in this way and for organizing the session at the 47th Annual Meeting of the Canadian Archaeological Association in 2015.

\section{REFERENCES}

Agbe-Davies, A.S., and Bauer, A.A. 2010. Rethinking trade as a social activity: An introduction. In: Bauer, A.A., and AgbeDavies, A.S., eds. Social archaeologies of trade and exchange: Exploring relationships among people, places, and things. Walnut Creek, California: Left Coast Press. 13-28.

Ames, K.M. 2002. Going by boat: The forager-collector continuum at sea. In: Fitzhugh, B., and Habu, J., eds. Beyond foraging and collecting: Evolutionary change in hunter-gatherer settlement systems. New York: Kluwer Academic/Plenum Publishers. $19-52$. https://doi.org/10.1007/978-1-4615-0543-3_2

Anstey, R.J., and Renouf, M.A.P. 2011. Down the Labrador: Ramah chert use at Phillip's Garden, Port au Choix. In: Renouf, M.A.P., ed. The cultural landscapes of Port au Choix: Precontact hunter-gatherers of northwestern Newfoundland. New York: Springer. 189-207.

https://doi.org/10.1007/978-1-4419-8324-4_10

Aporta, C. 2009. The trail as home: Inuit and their pan-Arctic network of routes. Human Ecology 37(2):131 - 146.

https://doi.org/10.1007/s10745-009-9213-x

Auger, R., and Stopp, M. 1989. 1986 archaeological survey of southern Labrador: Quebec/Labrador border to Cape Charles. In: Thomson, J.C., and Thomson, J.S., eds. Archaeology in Newfoundland and Labrador 1986. Annual Report 7. St. John's: Government of Newfoundland and Labrador. 198-212.

Bell, T., and Renouf, M.A.P. 2008. The domino effect: Culture change and environmental change in Newfoundland, 1500-1100 cal BP. The Northern Review 28(Winter):72-94.

__ 2 2011. By land and sea: Landscape and marine environmental perspectives on Port au Choix archaeology. In: Renouf, M.A.P., ed. The cultural landscapes of Port au Choix: Precontact hunter-gatherers of northwestern Newfoundland. New York: Springer. $21-41$.

Bell, T., Smith, I.R., and Renouf, M.A.P. 2005. Postglacial sealevel history and coastline change at Port au Choix, Great Northern Peninsula, Newfoundland. Newfoundland and Labrador Studies 20(1):9-31.

Binford, L.R. 1980. Willow smoke and dogs' tails: Huntergatherer settlement systems and archaeological site formation. American Antiquity 45(1):4-20. https://doi.org/10.2307/279653

2001. Constructing frames of reference: An analytical method for archaeological theory building using ethnographic and environmental data sets. Berkeley: University of California Press. 
Cannon, A., ed. 2014. Structured worlds: The archaeology of hunter-gatherer thought and action. Abingdon, Oxon: Routledge.

Carlstein, T. 1982. Time resources, society and ecology: On the capacity for human interaction in space and time, Vol. 1. Lund Studies in Geography, Series B, Human Geography No. 49. Crows Nest, New South Wales: Unwin Hyman.

Cartwright, G. 1792. A journal of transactions and events during a residence of nearly sixteen years on the coast of Labrador. Newark, United Kingdom: Allin and Ridge.

Cruikshank, J. 2015. Oral history, narrative strategies, and Native American historiography. In: Llewellyn, K.R., Freund, A., and Reilly, N., eds. The Canadian oral history reader. Montreal: McGill-Queen's University Press. 180-198.

Cummings, V. 2013. The anthropology of hunter-gatherers: Key themes for archaeologists. London: Bloomsbury Academic.

Cummings, V., Jordan, P., and Zvelebil, M., eds. 2014. The Oxford handbook of the archaeology and anthropology of huntergatherers. Oxford: Oxford University Press. https://doi.org/10.1093/oxfordhb/9780199551224.001.0001

David, B., Lamb, L., and Kaiwari, J. 2014. Landscapes of mobility: The flow of place. In: Cummings, V., Jordan, P., and Zvelebil, M., eds. The Oxford handbook of the archaeology and anthropology of hunter-gatherers. Oxford: Oxford University Press. $1164-1190$. https://doi.org/10.1093/oxfordhb/9780199551224.013.031

Fitzhugh, W.W. 1982. Smithsonian surveys in central and southern Labrador in 1981. In: Thomson, J.S., and Thomson, C., eds. Archaeology in Newfoundland \& Labrador 1981. Annual Report 2. St. John's: Historic Resources Division, Department of Culture, Recreation \& Youth, Government of Newfoundland and Labrador. 32-55.

Harp, E., Jr. 1976. Dorset settlement patterns in Newfoundland and southeastern Hudson Bay. In: Maxwell, M.S., ed. Eastern Arctic prehistory: Paleoeskimo problems. Memoirs of the Society for American Archaeology No. 31. 119-138.

Hodgetts, L.M. 2005. Using bone measurements to determine the season of harp seal hunting at the Dorset Palaeoeskimo site of Phillip's Garden. Newfoundland and Labrador Studies 20(1):91-106.

Kelly, R.L. 1992. Mobility/sedentism: Concepts, archaeological measures, and effects. Annual Review of Anthropology $21: 43-66$. https://doi.org/10.1146/annurev.an.21.100192.000355

Leblanc, S. 1996. A place with a view: Groswater subsistencesettlement patterns in the Gulf of St. Lawrence. MA thesis, Department of Anthropology, Memorial University of Newfoundland.

Lee, R.B., and Daly, R. 1999. Introduction: Foragers and others. In: Lee, R.B., and Daly, R., eds. The Cambridge encyclopedia of hunters and gatherers. Cambridge: Cambridge University Press. 1-22.

Loring, S. 2002. "And they took away the stones from Ramah": Lithic raw material sourcing and eastern Arctic anthropology. In: Fitzhugh, W.W., Loring, S., and Odess, D., eds. Honoring our elders: A history of eastern Arctic archaeology. Washington, D.C.: Smithsonian Institution. 163-185.
Loring, S., and Cox, S. 1986. The Postville Pentecostal Groswater Site, Kaipokok Bay, Labrador. Palaeo-Eskimo Cultures in Newfoundland, Labrador and Ungava. Reports in Archaeology No. 1. St. John's: Memorial University of Newfoundland. 65-93.

Nagle, C. 1986. Flaked stone procurement and distribution in Dorset culture sites along the Labrador Coast. Palaeo-Eskimo Cultures in Newfoundland, Labrador and Ungava. Reports in Archaeology No. 1. St. John's: Memorial University of Newfoundland. 95-110.

Newlander, K.S. 2012. Exchange, embedded procurement, and hunter-gatherer mobility: A case study from the North American Great Basin. PhD thesis, Department of Anthropology, University of Michigan.

Pintal, J.-Y. 1998. Aux frontières de la mer: La préhistoire de Blanc-Sablon. Les Publications du Québec, Dossier 102. Québec, Collections Patrimoines et Municipalité de Blanc Sablon.

Plumet, P., Lascombes, C., Elliot, V., Laurent, M., and Delisle, A. 1994. La question de la coexistence du Paléoesquimau et de l'Amérindien: Recherches dans la region de Blanc-Sablon, Basse-Côte-Nord, Québec. Recherches Amérindiennes au Québec, Paléo-Québec No. 21.

Provincial Archaeology Office. 2015. Archaeology sites in Newfoundland and Labrador.

http://www.btcrd.gov.nl.ca/pao/arch_sites/

Quinlan, G., and Beaumont, C. 1981. A comparison of observed and theoretical postglacial relative sea level in Atlantic Canada. Canadian Journal of Earth Sciences 18(7):1146-1163.

https://doi.org/10.1139/e81-109

Renouf, M.A.P. 1991. Sedentary hunter-gatherers: A case for northern coasts. In: Gregg, S.A., ed. Between bands and states. Centre for Archaeological Investigations Occasional Paper No. 9. Carbondale: Southern Illinois University at Carbondale. 89- 107.

- 1993. Palaeoeskimo seal hunters at Port au Choix, northwestern Newfoundland. Newfoundland Studies 9(2):185-212.

- 1994. Two transitional sites at Port au Choix, northwestern Newfoundland. In: Morrison, D., and Pilon J.-L., eds. Threads of Arctic prehistory: Papers in honour of William E. Taylor, Jr. Ottawa: Archaeological Survey of Canada, Mercury Series 149. $165-195$.

1999. Prehistory of Newfoundland hunter-gatherers: Extinctions or adaptations. World Archaeology 30(3):403-420. https://doi.org/10.1080/00438243.1999.9980420

- 2003. A review of Palaeoeskimo dwelling structures in Newfoundland and Labrador. Études/Inuit/Studies 27 (1-2): $375-416$.

, ed. 2011a. The cultural landscapes of Port au Choix: Precontact hunter-gatherers of northwestern Newfoundland. New York: Springer.

2011b. On the headland: Dorset seal harvesting at Phillip's Garden, Port au Choix. In: Renouf, M.A.P., ed. The cultural landscapes of Port au Choix: Precontact hunter-gatherers of northwestern Newfoundland. New York: Springer. 131-160. https://doi.org/10.1007/978-1-4419-8324-4_7 
Scheiber, L.L., and Finley, J.B. 2011. Mobility as resistance. In: Sassaman, K.E., and Holly, D.H., Jr., eds. Hunter-gatherer archaeology as historical process. Tucson: University of Arizona Press. 167-183.

Schmidt, K.A. 1998. The consequences of partially directed search effort. Evolutionary Ecology 12(3):263-277. https://doi.org/10.1023/A:1006596015767

Sergeant, D. 1991. Harp seals, man and ice. Canadian Special Publication of Fisheries and Aquatic Sciences 114. Ottawa: Department of Fisheries and Oceans.

Spielmann, K.A. 1986. Interdependence among egalitarian societies. Journal of Anthropological Archaeology 5(4):279-312. https://doi.org/10.1016/0278-4165(86)90014-0

Stopp, M. 1994. Cultural utility of the cobble beach formation in coastal Newfoundland and Labrador. Northeast Anthropology 48:69-89.

. 1997. Long-term coastal occupancy between Cape Charles and Trunmore Bay, Labrador. Arctic 50(2):119-137. https://doi.org/10.14430/arctic1095
. 2002. Ethnohistoric analogues for storage as an adaptive strategy in northeastern subarctic prehistory. Journal of Anthropological Archaeology 21(3):301-328. https://doi.org/10.1016/S0278-4165(02)00004-1

- 2008. FbAx-01: A Daniel Rattle hearth in southern Labrador. Canadian Journal of Archaeology 32(1):96-127.

— 2013. Kitjigattalik - the Ramah chert quarries. Historic Sites and Monuments Board of Canada Report Number 2013 15. Gatineau, Quebec: Parks Canada.

— ed. 2016. George Cartwright's The Labrador Companion. Montreal: McGill-Queen's University Press.

Weig, D. 2013. Motility and relational mobility of the Baka in north-eastern Gabon. PhD thesis, University of Cologne.

Wells, P.J., and Renouf, M.A.P. 2014. Dorset sled-shoe design and cold-season transport at Phillip's Garden (EeBi-1), northwestern Newfoundland. Arctic Anthropology 51(1):1 - 23. https://doi.org/10.3368/aa.51.1.1

Whallon, R. 2006. Social networks and information: Non"utilitarian" mobility among hunter-gatherers. Journal of Anthropological Archaeology 25(2):259-270.

https://doi.org/10.1016/j.jaa.2005.11.004 